\title{
Sesame (Sesamum indicum L.) Research and Production Status in Ethiopia: A Comprehensive Review
}

\author{
Merga Boru \\ Department of Crop Research, Assosa Agricultural Research Centre, Assosa, Ethiopia \\ Email address: \\ mergaboru23@gmail.com \\ To cite this article: \\ Merga Boru. Sesame (Sesamum indicum L.) Research and Production Status in Ethiopia: A comprehensive Review. Ecology and \\ Evolutionary Biology. Vol. 6, No. 2, 2021, pp. 38-41. doi: 10.11648/j.eeb.20210602.12
}

Received: January 15, 2021; Accepted: February 2, 2021; Published: April 29, 2021

\begin{abstract}
Sesame (Sesamum indicum L., 2n=26) grouped under the family Pedaliaceae; is probably the most ancient oil seed known and used by man. It is called 'Queen of oil seeds' due to its high quality polyunsaturated stable fatty acid. The availability of large amount of wild forms of sesame in Ethiopia show that it is indigenous and considered as the center of origin for sesame and the genetic diversity is high, serving as resources for further improvement of the crop. Sesame improving research was started in Ethiopia at Werer Agricultural Research Center with the target to develop high yielding and adaptable varieties which meet the demands of the sesame farmers, processor and user. A lot of varieties released by different research centers and most of the varieties are under production in different agro ecologies of Ethiopia. It is foreign currency generating crop next to coffee in Ethiopia and the leading crop from all oil crops growing in the country. Therefore, the main objective of this paper is to access the current sesame research and its production status in Ethiopia so that the information can be used as a good reference resource for researchers, students, agricultural extension workers and NGOs working in Ethiopia in the area of oil crops in general and sesame in particular.
\end{abstract}

Keywords: Sesame, Production, Research, Ethiopia, Oil Crops, Foreign Currency

\section{Introduction}

Sesame (Sesamum indicum L., 2n=26) grouped under the family Pedaliaceae; is probably the most ancient oil seed known and used by man [1]. It is called 'Queen of oil seeds' due to its high quality polyunsaturated stable fatty acid, which restrains oxidative rancidity [2]. It is also stable due to the natural antioxidants sesamol and sesamolinol that reduce the rate of oxidation [3]. The crop is grouped in the Pedaliaceae family and adapted to hot areas [1]. It was one of the first oil seeds from which oil was extracted by the ancient Hindus, which was used for certain ritual purposes [4]. Sesame is an ancient oilseed, first recorded as a crop in Babylon and Assyria before 2050 BC [5].

Globally, sesame seed consumption was USD 6559.0 million in 2018, and it will reach USD 72449 million by 2024 , with a compound annual growth rate of $1.7 \%$ (Mordor Intelligence Home Page 2020-2025). Global sesame consumption is steadily increasing mainly due to changing consumer's consumption patterns and increasing health awareness. Currently, the consumers mostly prefer the high nutritive value products. Due to this reason, the need for sesame seeds is increasing since it has several nutritional characteristics such as vitamins, minerals, fiber, healthy fat, and protein. About $70 \%$ of the world's sesame seed is used to produce oil and meal. Total annual oil and food consumption is about $65 \%$ and $35 \%$, respectively [6].

Different scholars indicated that Ethiopia is among the topfive sesame producing countries in the world, ranked at fourth place [7]. Therefore, Ethiopia is the third exporter of sesame seed after India and Sudan [8]. In addition, sesame is the major oilseeds crop in the country in terms of exports next to coffee, which accounts over 90 percent of the value of oilseeds exports. Reports indicate that the country has still immense potential arable land in different areas of the country to produce the crop and there is a considerable demand for Ethiopian sesame seed at international markets especially the Humera and Gondar production [9]. This indicates that, growth and improvement of the sesame sector can substantially contribute to the economic development at national, regional and family levels.

Ethiopia's export share $1.5 \%$ in volume and $1.9 \%$ in value 
to World market in 1997 had grown to $8.9 \%$ and $8.3 \%$ in 2004 respectively [10]. Sesame plays a significant role in the livelihood of sesame growing farmers in Ethiopia. In the western part of Tigray (Humara, Welkayit and the Tahtay Adiabo), Amhara (Wollo and Metema), Benishangul and Gambella, farmers produce sesame as a major cash crop.

\subsection{Historical Back Ground of the Crop}

Many of the scholars indicate that two centers of origins might be East Africa (Ethiopia) or Asia (Indian Subcontinent or further east or central Asia) proposed. East Africa and India as early origins for Sesame [11]. Africa as the original home of sesame, since this continent hosts high number of wild species [12]. The availability of large amount of wild forms of sesame ( $S$. alatum; $2 \mathrm{n}=26$ and $S$. latifolium, $2 \mathrm{n}=32$ ) in Ethiopia show that it is indigenous and considered as the center of origin for sesame and the genetic diversity is high, serving as resources for further improvement of the crop [13]. There is very high genetic diversity among sesame collections from these different regions [14]. While, the genetic diversity of Ethiopian sesame landraces and cultivars showed the existence of great genetic variability between the landraces and SSR markers were established for further diversity analyses of Ethiopian sesame and establishment of a core collection [13]. Domestication of sesame is about 5000 years old were found in archaeological excavations in Harappa [15]. Sesame has been cultivated for centuries in India, Pakistan, Burma, Indo-China, China, Japan and Africa. Currently, sesame has been introduced into Mexico, Central America, South America, and the U.S.A [16]. Sesame is one of the world's oldest spice and oilseed crop and it is native to tropic and sub-tropic regions. Because of its increasing in export value, its production area has been extending to new areas previously not known in sesame production.

\subsection{Production Status of Sesame in Ethiopia}

Now days, the world sesame production is about 5,532,000 metric tons (MT) behind soybean, groundnut, cottonseed, sunflower, linseed, and rapeseed. India, Myanmar, and China the highest producers among the sesame producing countries. Myanmar is one of the top ten sesame producing countries and ranks the third largest in cultivated area and the second largest in production [17].

Sesame is economically important to Ethiopia, as it ranks as a top performing export crop. In Ethiopia oilseed is the $3^{\text {rd }}$ largest crop sector in area coverage after cereals and pulses. In 2017/18, Oil seeds added $6.68 \%$ (about $846,493.53$ hectares) of the grain crop area and $2.79 \%$ (about 8,550,738.16 quintals) of the production to the national grain total. Neug, sesame and linseed covered 2.29\% (about 290,494.94 hectares), 2.92\% (about 370,141.06 hectares) and $0.62 \%$ (about 79,044.51 hectares) of the grain crop area and $1.06 \%$ (about 3,233,448.82 quintals), $0.84 \%$ (about 2,559,034.30 quintals) and $0.29 \%$ (about 882,096.51 quintals) of the grain production, respectively [19] and sesame ranks 1st from the oil seeds sectors which accounts a total land coverage of 370,141 hectare which estimated production of about 2,559,034 quintal in $2017 / 18$ cropping season [18].

Table 1. Sesame production status by region in Ethiopia.

\begin{tabular}{lll}
\hline Region & Area cultivated (Ha) & Production in quintal \\
\hline Tigray & 122,325 & 746142 \\
Amahara & 171,877 & $1,237,278$ \\
Diredawa & 103 & 1074 \\
Benishangul Gumuz & 29033 & 213,687 \\
\hline
\end{tabular}

Source: CSA 2018

\subsection{Contribution of Sesame to National Economy}

Ethiopia is one of the fastest growing countries in east Africa. However, the import export balance is with billions of USD deficit (14 billion, in 2015) for many years. Sesame locally called "Selit" and nicknamed as "White Gold" is a cash crop and the sector is millions of dollars industry that supports the livelihoods of thousands of small farmers, medium-to large scale private farms along with thousands of other actors involved in the chain of production-toconsumption/export continuum. Sesame with attractive domestic and international market is the second (next to coffee) important crop in earning foreign currency as indicated by Fiseha and Zenawi [19]. Traditional importers of Ethiopian sesame seed were China, Israel, Turkey and other Middle Eastern countries". While currently, the demand volume of the traditional buyers is continuing to increase and new importers such as Greece, Germany, The Netherlands and United Kingdom are also coming to the market from which foreign currency was generated [9]. The Global sesame annual production in 2018 is estimated to be more than 5 million MT annually according to Global Agricultural Information Network Report on 2018. Ethiopia production of sesame seed is estimated to increase to 340,000 MT that would have a trading value of US \$1 Billion. According to Global Agricultural Information Network Report on 2018 the major importers of Ethiopian sesame are China (45\%) and Israel $(20 \%)$ [9].

\section{History of Sesame Research in Ethiopia}

Sesame research in Ethiopia was date back to 1960s by Institute of Agricultural Research (IAR) at Werer Agricultural Research Center (WARC) under irrigation with collected genotypes and exotic germplasms from abroad. The main target was to develop new variety with high potential which meet the demands of the sesame growers, processor and consumer. Ethiopian sesame breeders have used the methods involving the use of collection, introduction, selection (mass and pure line), and hybridization (followed by pedigree and bulk method of breeding) and recently induced mutation [20]. During the research periods, three broad activities were undertaken. These were collection, introduction, and characterization and evaluation phase of sesame germplasm for identifying best adaptable sesame cultivars for the 
potential areas. Second, incorporation of crossing program into the already pre-existing breeding methods. Third phase was marked by the initiation of molecular approaches including analyses of molecular genetic diversity, development of molecular markers and initiation of induced mutation techniques particularly for pod shattering [21].

There were many achievements of sesame research works in Ethiopia. New varieties which are adaptable to different agro ecologies of the countries and high yielder were released. Some of them are under production in different parts of sesame producing areas and some are still under testing for various agronomic parameters under different climatic and soil conditions of the country [22].

There is some improved varieties of sesame released in Ethiopia at different agro ecologies and Universities.

Table 2. Achievements of improved sesame varieties released by different national and regional research centers starting from 1993 to 2018.

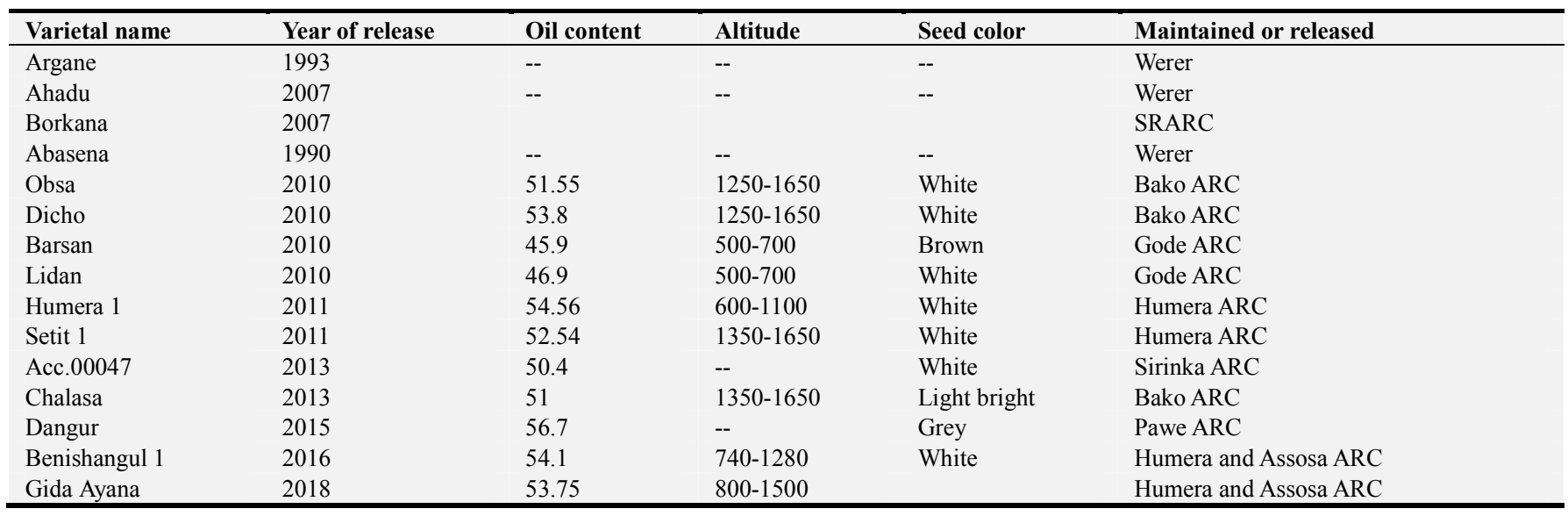

Source: MoARD, crop variety register book 1993 - 2018

\section{Conclusion}

Sesame (Sesamum indicum L., 2n=26) grouped under the family Pedaliaceae; is probably the most ancient oil seed known and used by man. It is called 'Queen of oil seeds' due to its high quality polyunsaturated stable fatty acid, which restrains oxidative rancidity, it is also stable due to the natural antioxidants sesamol and sesamolinol that reduce the rate of oxidation The crop is grouped in the Pedaliaceae family and adapted to hot areas. Africa is considered as the original home of sesame, since this continent hosts high number of wild species. The availability of large amount of wild forms of sesame ( $S$. alatum; $2 \mathrm{n}=26$ and $S$. latifolium, $2 n=32$ ) in Ethiopia show that it is indigenous and considered as the center of origin for sesame. Sesame research in Ethiopia was started in 1960s by Institute of Agricultural Research (IAR) at Werer Agricultural Research Center (WARC) under irrigation and now a day's many improved varieties were released which are under production. These released varieties are playing a great role in exported sesame crops which are generating foreign currency to the country next to coffee. Even though the breeding part was carried out for many years and promising achievements were obtained, the agronomic parts of the crop was neglected and the productivity is still low which needs future research direction.

\section{References}

[1] Reddy, S. (2006). Agronomy of field crops. New Delhi: Kalyani Publishers.
[2] Weiss, E. A. (2000). Oil seed Crops 2nd edition. Black well Science, Inc., Malden.

[3] Tafere, G., Wakjira, A., Berhe, M., \& Tadesse, H. (2012). Sesame Production Manual. EIAR.

[4] Arnon, I. (1972). Crop production in dry regions. Vol. II: Systematic treatment of the principal crops (pp. 683). Leonard Hill, London. Retrieved: http://www.worldcat.org/title/cropproduction-in-dry-regions/oclc/417518.

[5] Seegeler, C. J. P. (1983). Oil plants in Ethiopia, their taxonomy and agricultural significance. [sn]. Centre for Agricultural Publishing and Documentation, Wageningen.

[6] Morris, J. B. Food, industrial, nutraceutical, and pharmaceutical uses of Sesame genetic resources. In Trends.

[7] FAOSTAT: http://www.FAOSTAT.Com -Top Five Sesame Seed Producing Countries.

[8] Alemu, Dawit and Gerdien W. Meijerink (2010); Sesame Traders and the ECX: An Overview with Focus on Transaction Costs and Risks, VC4PPD Report \#8, Addis Ababa.

[9] Sorsa, Debela Gelalcha, (2009); Sesame trade arrangements, costs and risks in Ethiopia: A baseline survey. VC4PD Research Papers.

[10] Abera, H. (2009). Analysis of Sesame production, Supply, Demand and Marketing Issues in Ethiopia. Ethiopian Commodity Exchange Authority, Addis Ababa.

[11] Bedigian, D., Harlan, J. (1986). Evidence f or cultivation on sesame in the ancient world Economic Botany 40: 137-154.

[12] Hiltebrandt V. M., 1932. Sesame (Sesamum indicum L.). Bull. Appl. Bot. Plant Breed. 9. 
[13] Daniel E. G., and Parzies, H. K., 2011. Genetic variability among landraces of sesame in Ethiopia. African Crop Science Journal, 19 (1): 1-13.

[14] Laurent in, H. E., Karlovsky, P. (2006). Genetic relationship and diversity in a sesame (Sesamum indicum L.) germplasm collect ion using amplified fragment length polymorphism (AFLP). BMC Genetics 7: 10.

[15] Fuller, D. Q., 2003. Further evidence on the prehistory of sesame. Asian Agri-History, 7 (2): 127-137.

[16] Lalpantluangi, P. C. and Shah, P., 2018. Character association and path coefficient analysis in sesame (Sesamum indicum L.) genotypes under foothill condition of Nagaland. The Pharma Innovation, 7 (5b): 82.

[17] Food and Agricultural Organization Statistical Databases (FAOSTAT). Available online: http://faostat.fao.org./ (accesed at 8 January 2021).

[18] CSA (Central Statistical Agency) (2007). Federal Democratic Republic Ethiopia: Central statistics Agency, Agricultural sample survey 2018 (2010E.C) (September-December 2010).
Volume I: Report on: Area and production of crops (private peasant holdings, meher season), Statistical Bullet in 586, Addis Ababa, April, 2018. Pp. 1-17.

[19] Fiseha and Zenawi, 2019 Sesame (Sesamum indicum L.) Production, Productivity, Marketing and Its Economic Importance in Ethiopia Sesame (Sesamum indicum L.) Production and Productivity. An international Sesame Conference, Zhengzhou, China, 2019.

[20] Daniel E. G., 2017. Sesame (Sesamum indicum L.) Breeding in Ethiopia. International Journal of Novel Research in Life Sciences. 4 (1): 1-11.

[21] Woldesenbet, D. T., Tesfaye, K. and Bekele, E., 2015. Genetic diversity of sesame germplasm collection (Sesamum indicum L.): implication for conservation, improvement and use. International Journal of Biotechnology and Molecular Biology Research, 6 (2): 7-18.

[22] Chemeda, D., Amsalu, A., Hamtamu, Z. and Adugna, W., 2014. Association of stability parameters and yield stability of sesame (Sesamum indicum L.) genotypes in Western Ethiopia. East African Journal of Sciences, 8 (2): 125-134. 